\title{
FIQIH IBADAH VERSUS FIQIH MUAMALAH
}

\author{
Fathul A Aziz \\ aminazizcenter@gmail.com \\ Prodi Ekonomi Syariah \\ Fakultas Ekonomi dan Bisnis Islam IAIN Purwokerto
}

\begin{abstract}
Abstrak
People's understanding of fiqh of worship is only a matter for the happiness of the hereafter while understanding muamalah fiqh / Economy is for world happiness only. Understanding like this will have an impact on the radical behavior of Muslims, which is hard behavior and considers the separation absolutely necessary. Whereas in other propositions there are still many criteria for the process of worship to find happiness in the hereafter such as intention. Intention will determine whether an action is good or not good, right or wrong and there are many more propositions that make someone happy in the world and the hereafter.

The muamalah fiqh in this paper is limited to economic studies, in order to focus more closely on the extent of muamalah studies. This limitation is only an example, because the essence of muamalah is not an example, but rather the construction of the proposition.

Separation of world affairs and the hereafter on the other hand also has an impact on lagging in world civilization. Technology that is always changing and developing all the time cannot be balanced by some Muslims except as connoisseurs of technology. The emergence of new technology actually triggers inequality in society, and its inability to conclude that it is not important because of world affairs, unfortunately our helplessness when Muslims feel very left behind in technology actually triggers the separation of world science and the hereafter, and the choice is to build hatred that triggers the emergence of the movement radical behavior. No longer heard the movement of a creative generation of young Muslims, gradually vanished eroded by the logic of looking for happiness in the hereafter by leaving world activities. The reality that occurs is precisely concerning the younger generation of Islam, even they are sometimes willing to sacrifice themselves to find happiness in the hereafter with suicide bombings using the logic of jihad. Data from the Wahid Institute in 2016 showed that $7.7 \%$ of Indonesians claimed to be willing to participate, and $0.4 \%$ had participated in activities that could potentially cause violence in the name of religion, while $72 \%$ disagreed with radicals.
\end{abstract}

Keyword : Fiqih, Ibadah, Fiqih, Muamalah. 


\section{A. Pendahuluan}

Dalam dekade terakhir ini umat Islam terlihat nyaring perdebatan di media sosial maupun di majlis-majlis ta'lim/liqo/pengajian tentang perdebatan dunia atau akherat. Perdebatan tidak selesai pada wilayah itu saja akan tetapi sampai pada perdebatan siapa siapa yang berhak menerima imbalan pahala dan dosa serta siapa yang berhak menempati surga dan siapa yang bisa menempati neraka. Nampak jelas umat muslim menempati tangga terbawah dalam peradaban dan pergaulan dunia, karena dalam internal umat Islam sendiri, saling melecehkan, saling menghakimi, saling mencaci, saling memaki. Padahal wilayah perdebatan ada di wilayah fiqih yang aspek kebenaranya masih bersifat nisbi.

Umat Islam tidak bisa lepas dari ajaran syariatnya, salah satunya adalah hukum fiqih. Fiqih menjadi urgen karena berkaitan dengan metode beribadah, cara, interaksi sosial, dan masih banyak lainya. Seringkali terjadi perseteruan antara pemeluk agama dan internal agama diawali dari adanya perbedaan penafisiran atas dalil yang mereka fahami.

Banyak para ilmuwan meneliti dan menyimpulkan dariberbagai jurnal dan media bahwa perilaku radikal penyebabnya adalah faktor ekonomi. Hal ini terbantahkan ketika di pengadilan atau ketika diwawancarai wartawan bahwa mereka melakukan kegiatan tersebut atas dasar mencari kebahagiaan ukhrowi (akhirat).

Fenomena munculnya pemisahan perbuatan dunia (fiqih Muamalah/Ekonomi) dan akhirat (fiqih ibadah) adalah diawali ketika maraknya perdebatan akan adanya perbuatan yang dianggap ibadah dan bukan ibadah atau urusan dunia dan urusan akhirat. Konstruk berfikir umat terbagi menjadi dua pilihan, apakah akan melakukan perbuatan yang mengakibatkan kebahagiaan dunia atau perbuatan yang akan berakibat pada kebahagiaan di akhirat, dan akhir dari perdebatan tersebut adalah pilihannya cenderung untuk mendapatkan kebahagiaan akhirat yang abadi.

Pemahaman umat atas fiqih ibadah adalah urusan untuk kebahagiaan akhirat semata sementara pemahaman fiqih muamalah/Ekonomi adalah untuk kebahagiaan dunia semata. Pemahaman seperti ini akan berdampak pada perilaku radikal umat muslim, yakni perilaku yang keras dan menganggap pemisahan itu mutlak adanya. Padahal dalam dalil lain masih banyak kriteria proses ibadah untuk menemukan kebahagiaan akhirat seperti Niat. Niat akan menentukan apakah sebuah perbuatan itu baik atau tidak baik, benar atau salah dan masih banyak lagi dalil yang menjadikan seseorang bahagia dunia dan akhirat. 
Fiqih muamalah dalam tulisan ini dibatasi pada kajian ekonomi, dalam rangka untuk lebih memfokuskan telaah atas luasnya kajian muamalah. Pembatasan ini hanya sebagai contoh semata, karena esensi muamalah bukan pada contohnya akan tetapi lebih pada konstruksi dalilnya.

Pemisahan urusan dunia dan akhirat disisi lain juga berdampak pada ketertinggalan dalam peradaban dunia. Teknologi yang selalu berubah dan berkembang setiap saat tidak dapat diimbangi oleh sebagian umat muslim kecuali sebagai penikmat teknologi. Munculnya teknologi baru justru memicu ketimpangan di masyarakat, dan ketidakmampuannya kemudian menyimpulkan bahwa itu tidak penting karena urusan dunia, celakanya ketidakberdayaan kita umat muslim ketika merasa sangat tertinggal dalam bidang teknologi justru memicu pemisahan ilmu dunia dan akhirat, dan pilihannya adalah membangun kebencian yang memicu munculnya gerakan perilaku radikal. Tidak lagi terdengar gerakan generasi muda Islam yang kreatif, lambat laun menghilang tergerus oleh logika mencari kebahagiaan akhirat dengan meninggalkan aktifitas dunia. Realitas yang terjadi justru memprihatinkan generasi muda Islam, bahkan mereka kadang rela mengorbankan dirinya untuk mencari kebahagiaan akhirat dengan bom bunuh diri dengan menggunakan logika jihadnya. Data dari Wahid Institut tahun 2016 menujukan bahwa 7,7 \% masyarakat Indonesia mengaku bersedia berpartisipasi, dan $0,4 \%$ pernah berpartisipasi dalam kegiatan yang berpotensi menimbulkan kekerasan atas nama agama, sedangkan $72 \%$ tidak sepaham dengan radikal.

Imam Ghozali salah satu yang mempelopori adanya pemilahan perebutan dunia dan akhirat, alasan yang mendasarinya adalah karena komunitas umat Islam pada waktu itu sangat tinggi penggunaan nalar rasionalitasnya (aqli), sehingga penggunaan dalil keagamaan terabaikan dan bahkan terkadang menyimpang jauh dari yang dikehendaaki dalil naqli-nya.

Padahal seharusnya ada keseimbangan (balance) antara penggunaan dalil naqli dan dalil aqli. Namun, saat ini umat sangat membutuhkan peran akal dalam rangka memahami teks keagamaan. tidak secara tekstual melainkan secara konstektual dan berkonstribusi dalam mewujudkan serta memenangi persaingan peradaban dunia. Begitu juga munculnya fiqih pada masa Imam Syafii dilandasi atas maraknya tasawuf yang menafikan proses syar'inya. 
Disisi lain keragaman penafsiran adalah ruang akal untuk menafsirkan pesan Allah SWT. Kebenaran hakiki milik Allah SWT. Karena pesan Allah SWT dalam Al Quran bersifat universal. Ada hubungan antar ayat dan ada hubungan antara ayat dengan hadits. Ikatan ibadah selalu berhubungan dengan syariat dan hakikat. Syariat lebih berhubungan dengan perintah, syarat dan rukun. Sementara hakikat lebih berhubungan dengan tujuan yakni kecintaan kepada Allah SWT. Jika dua kondisi itu terpenuhi maka ibadah baru dikatakan sempurna. Dan hal ini yang tahu hanya individu dan Tuhanya.

Umat Islam sudah saatnya untuk melirik pesan Allah SWT yang menghadirkan Islam sebagai rohmatan lil'alamin, yang bukan hanya memberikan kesejahteraan dan kenyamanan hidup pribadi, akan tetapi mampu menyejukan seluruh umat. Umat Islam harus memiliki agenda untuk menjadikan logika berfikir awal yang mampu mempersatukan umat tanpa lelah mencari lemahnya yang lain akan tetapi bagaimana membangun persatuan untuk kita saling mencintai antar umat Islam, ditengah perbedaan.

\section{B. Fiqih Ibadah (Mahdlah)}

Menurut bahasa fiqih bermakna pemahaman. Adapun beberapa ulama memiliki ta`rif berbeda mengenai fiqih. Secara syara diantaranya; Abu Hanifah mendefinisikan fiqih sebagai pengetahuan manusia akan dirinya dan segala yang terkait dengan kemanusiaan. Abu Abdilah asSyafii menyatakan pendapatnya mengenai fiqih yaitu sebagai ilmu pengetahuan, ketentuan Tuhan yang berkaitan dengan segala tindakan manusia yang memiliki dampak hukum berdasarkan perintah Tuhan. Imam Showi menjelaskan bahwa fiqih adalah mengambil agama Allah dan teguh menjalankan seluruh perintah dan menghindari apa yang menjadi larangan-Nya. ${ }^{1}$

Secara lebih spesifik kemudian fiqih diklasifikasikan menjadi dua. Pertama, fiqih ibadah yaitu semua perbuatan yang berkaitan dengan Thaharoh, Shalat, Puasa, Zakat, Haji, Qurban, Nadzar, Sumpah dan semua perbuatan manusia yang berhubungan dengan Tuhannya. Kedua, fiqih muamalat yaitu semua bentuk kegiatan transaksional seperti; deposito, jual

${ }^{1}$ Muhammad Nawawi, "Syarhul Muraqil 'Ubudiyah" (Pekalongan: Maktabah Raja Murah) Hlm. 4 
beli, pidana, perdata antar sesama manusia baik secara individu maupun lembaga bahkan negara. ${ }^{2}$

Menjadi keniscayaan bahwa kita dalam beribadah harus menggunakan ilmu atau menjadi syarat sebelum kita beribadah mencari ilmu terlebih dahulu karena kedudukan ilmu itu laksana pohon, dan ibadah itu adalah buah dari berbagai jenis buah pepohonan (ilmu). Wajib bagi kita yang pertama untuk mengenal al-Ma`bud, karena bagaimana kita akan menjalankan pengabdian kalau kita tidak mengenal dari Asma, Sifat DzatNya, apa yang mungkin dan apa yang tidak mungkin menyertai dzat-Nya agar kita terhindar dari penisbatan pensifatan yang keliru terhadap-Nya.

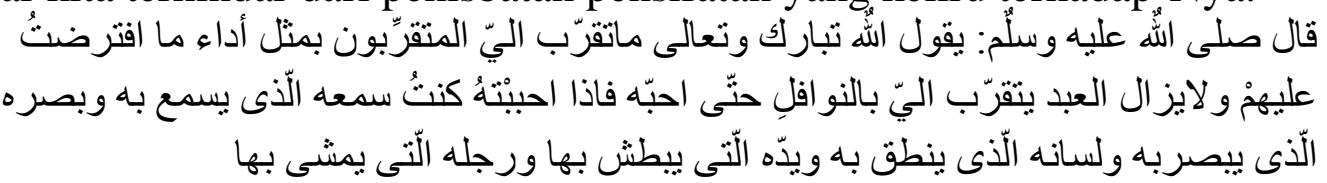

Hadits qudsi di atas mengisyaratkan bahwa perintah Allah SWT ada yang bersifat Fardlu dan Nawafil. Fardlu adalah perintah yang bersifat wajib dan menjadi dasar dari bentuk penghambaan dan pengabdian. Sedang Nawafil adalah keuntungan dan kemenangan yang memiliki derajat (Tingkatan).

Beberapa contoh kajian fiqih ibadah dalam kitab-kitab ulama salaf adalah antara lain:

\section{Thaharah}

Dalam praktik peribadahan atau awal bagian yang harus diperhatikan adalah thaharah. Seperti penjelasan dalam hadits berikut; karena thaharah kunci shalat dan merupakan syarat sahnya shalat:

مفتاح الصلاة الطّهور, وتحريمها التكبير, وتحليلها التسليم3

Thaharah secara bahasa adalah bersih dari segala kotoran atau najasah. Adapun menurut syara` thaharah memiliki makna bersih dari segala macam najis baik yang bersifat hakikat, aib dan perbuatan maksiat atau yang bersifat hukmiyah; hadats besar, hadats kecil (kencing) dll. Imam Nawawi As-syafi i mendefinisikan thaharah adalah menghilangkan atau mensucikan diri dari hadats besar dan hadats kecil maupun menghilangkan bentuk dari kedua hadats tersebut seperti dalam firman Allah dalam surat 2 ayat 125 dan surat 74 ayat 4.

\footnotetext{
${ }^{2}$ Wahbah. Z, Kitab "Fighul islami wa adalatih" (Damaskus: Maktabah Darul Fikr, 2005)

3 "Fiqhul islami wa adalatih" (Damaskus: Maktabah Darul Fikr, 2005) juz 1, hlm 237
} 
Dalam masalah thaharah para ulama sepakat terkait alat, media yang dapat digunakan untuk bersuci adalah air dan debu/batu. Namun, dalam kehidupan sekarang alat untuk bersuci khususnya air telah mengalami perkembangan dan membutuhkan perhatian serius. Persoalan pengairan telah berkembang sangat pesat tehnologinya dan menjadi peluang bagi kehidupan manusia dari sisi manfaat (nilai ekonomi). Hal ini senada dengan pemahaman para ahli ushul bahwa Nash kebanyakan menggunakan shighot takhshis (khusus) yang di dalamnya mencakup penjelasan hukum umum. ${ }^{4}$

Sarana menuju kesempurnaan berwudlu menjadi sebuah perbuatan yang memiliki nilai pahala karena akan memudahkan dalam penyempurnaan thoharoh/wudlu.

\section{Shalat}

Do`a (mengharap kebaikan) merupakan makna dari shalat secara lughot (QS. 9 : 103), secara syar $i$ shalat merupakan gabungan dari perbuatan dan ucapan khusus yang diawali dengan pengucapan takbir dan diakhiri dengan salam. Adapun salah satu tujuan dari disyariatkannya shalat adalah untuk mewujudkan rasa sukur terhadap banyaknya kenikmatan yang Allah berikan, disamping itu shalat juga memiliki manfaat yang bersifat diniyah yang paling fundamental adalah keshalihan mental/ kejiwaan (QS. 70 : 19 - 21) dan juga memiliki manfaat secara ijtimaiyah (sosial). ${ }^{5}$ Tidak seperti ibadah yang lain, shalat memiliki ketentuan waktu yang jelas (QS. 4 : 103). Pada penentuan waktu pelaksanaan shalat secara ekplisit menjelaskan mekanisme keilmuan yang bersifat dinamis seperti; penemuan alat penunjuk arah (kompas), penentuan waktu isyraq dan ghurubussyams ${ }^{6}$ yang mengisyaratkan peluang kajian shalat secara lebih masif dari berbagai disiplin keilmuan tidak juga kajian ekonomi dan industri. ${ }^{7}$ Istinbath hukum yang kita gunakan adalah pendekatan ushul fiqih yang menjadi rujukan dari permasalahan yang terjadi hari ini. Keterkaitan teknlologi bagi sempurnanya pelaksanaan peribadatan adalah sebuah keniscaayaan seperti pada kajian thaharah dalam pelaksaan shalat juga tidak mungkin lepas dengan dunia industri.

\footnotetext{
${ }^{4}$ Muhamad Rasyid kitab “Ashbabunnuzul wa atsariha fibayani nushus” (Darus Syihab, 1999) Hlm. 370

5 “Fiqhul islami wa adalatih” (Damaskus: Maktabah Darul Fikr, 2005) juz 1, hlm. 657

6 "Fiqhul islami wa adalatih" (Damaskus: Maktabah Darul Fikr, 2005) juz 1, hlm. 663

7 "Fiqhul islami wa adalatih" (Damaskus: Maktabah Darul Fikr, 2005) juz 1, hlm. 692
} 
المشقة تجلب التيسير

Kaidah di atas (usul fiqih) menjelaskan bahwa persoalan kekeringan yang melanda dunia saat ini dan kebutuhan manusia akan teknologi pengairan dan industri tekstil adalah syarat yang tidak bisa kita nafikan bagi terwujudnya ibadah. Imam Izzudin bin Abdussalam memiliki penjelasan dalam teorinya bahwa kajian fiqih secara umum adalah bertujuan mencarikan ta`bir bagi terciptanya kemaslahatan dan bagaimana menolak keburukan.

الاجرة عقبة بن عامر إنّ الّّ يدخل بالسهم الواحدالثناثة الجنّة, وفيه: وصانعة يحتسب فى صنعته

Hadits di atas mengisyaratkan bahwa memproduksi alat yang dibutuhkan bagi umat untuk melaksanakan ibadah adalah memiliki nilai ibadah (manfaat). ${ }^{8}$ Absah-nya Shalat sebagai salah satu rukun Islam memiliki tata-cara (syuruthu as-shalat) yang tidak bisa ditinggalkan seperti sahnya bentuk ibadah yang lain. Menurut bahasa syarath adalah petunjuk, menurut syariat; petunjuk yang dengannya tercapai keabsahan shalat tetapi bukan merupakan bagian dari shalat. Adapun, rukun menurut bahasa adalah bagian yang harus ada, menurut istilah; bagian yang harus ada pada setiap pelaksanaan shalat karena merupakan bagian dari shalat. ${ }^{9}$

Syarat wajibnya shalat (Syuruthu Wujuba as-sholati)

1) Islam. Shalat hanya diwajibkan bagi orang yang beragama Islam laki-laki dan perempuan. Menurut pendapat jumhur tidak diwajibkankan shalat bagi non-muslim terkait dengan keabsahan pelaksanaannya.

2) Dewasa (Baligh). Shalat tidak diwajibkan bagi anak-anak berdasarkan salah satu hadits yang diriwayatkan dari Ali bin Abi Tholib dan Umar bin Khathab oleh Imam Ahmad, Abu Dawud dan Alhakim.

3) Tidak kehilangan akal (gila).

Syarat sahnya shalat (Syuruthu Shihata as-sholati)

1) Niat

2) Mengetahui waktu shalat. Tidak sah pelaksanaan shalat di luar waktu yang telah ditentukan

3) Suci dari hadats kitab al-libas

4) Suci dari kotoran (najis) QS.74 : 4

5) Menutup aurat. ${ }^{10}$

${ }^{8}$ Abdurahman as-Suyuthi “Asybah wa Nadhair” (Bairut: Darul Kitab Alamiyah, 1983) Hlm. 8

9 "Fiqhul islami wa adalatih" (Damaskus: Maktabah Darul Fikr, 2005) juz 1, hlm. 722

${ }^{10}$ Abdurrahman bin Nasir Al barrak, Abu Qutaibah N. M. Al faryabi "Fathul Barri bi Syarhil Bukhori” (Riyadh : Darul Thaibah, 2005) juz 13. Hlm .249 
6) Menghadap kiblat

7) Menggunakan bahasa arab

8) Tidak bergerak diluar gerakan shalat

9) Tertib.

Sholat memiliki wilayah ibadah yang tidak lepas dengan ruang syarat. yang pertama, menutup aurat, dalam menutup aurat tidak lepas dengan kebutuhan "duniawi" yaitu kain yang digunakan sebagai pakaian seorang muslim, kedua, masjid adalah alat yang digunakan sebagai tempat peribadatan, dan lain sebagainya, dimana klasifikasinya masuk ke dalam fiqih muamalah.

\section{Haji}

Artinya:

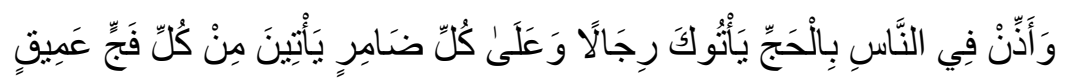

"Dan umumkanlah (wahai Ibrahim) kepada sekalian manusia tentang kewajiban haji atas mereka, niscaya mereka akan datang kepadamu dalam keadaan berbeda-beda; berjalan kaki dan menunggangi unta yang kurus (yaitu unta yang kurus karena perjalanan dan beban pekerjaan bukan karena berdaging sedikit) yang tiba dari segenap jalan yang jauh." - Surat Al-Hajj Ayat 27.

Ayat diatas mengisyaratkan bahwa pelaksanaan Haji disamping karena kewajiban yang bersifat mahdloh juga adanya persiapan, sarana yang dibutuhkan untuk menunaikannya (Kitab al-Haj) ${ }^{11}$. Supaya mereka menghadiri hal-hal yang bermanfaat bagi mereka, berupa: pengampunan bagi dosa-dosa mereka, pahala mengerjakan manasik haji dan ketaatan mereka, serta perolehan keuntungan dalam perniagaan mereka dan kepentingan-kepentingan lain, dan agar mereka menyebut nama Allah ketika menyembelih hewan (Nusuk), kurban yang mereka jadikan pendekatan diri kepada Allah, seperti unta, sapi dan kambing pada hari-hari tertentu, yaitu tanggal 10 Dzulhijjah dan tiga hari setelahnya, sebagai ungkapan rasa syukur kepada Allah atas nikmat-nikmat-Nya. sedang mereka diperintah sebagai anjuran saja untuk memakan dari sembelihan-sembelihan tersebut dan memberikan makan orang fakir yang amat sulit ekonominya dari sembelihan itu. Dengan adanya penjelasan tersebut diatas jelas bahwa ibadah mahdhah tidak dapat terlepas dari urusan "duniawi".

${ }^{11}$ Abi yahya Zakaria al- Anshori "Fathul Wahab bi Syarhi Minhaju at-Thulab" (Al Haramain, 2008) Juz 1. Hlm.135 


\section{Fiqih Muamalah (Ghoiru Mahdloh)}

Fiqih muamalah berasal dari kata 'amala yu'amili mu'amalatan yang berarti saling bertindak, saling berbuat, saling beramal. Dalam istilah bermakna hasil ijtihad seseorang atau sekelompok orang tentang hukum bagi berbagai macam transaki/kegiatan manusia yang dilakukan sesuai dengan ajaran Islam. Salah satu kajian dalam fiqih muamalah adalah Ekonomi. Secara umum pengertian ekonomi adalah salah satu ilmu sosial yang mempelajari aktivitas manusia yang berhubungan dengan produksi, distribusi dan konsumsi terhadap barang dan jasa. ${ }^{12}$

Dalam perkembangan terakhir ini fiqih muamalah mengenalkan tentang adanya modal sosial. Modal sosial dapat didefinisikan sebagai serangkaian nilai dan norma informal yang dimilki bersama diantara para anggota suatu kelompok masyarakat yang memungkinkan terjadinya kerjasama diantara mereka (Francis Fukuyama, 2002: xii). Kapital sosial berhubungan dengan nilai kolektif dalam sebuah jaringan sosial yang tumbuh-kembang sebagai implikasi dari hubungan-hubungan timbal balik yang terjadi didalamnya. ${ }^{13}$

Tiga unsur utama dalam modal sosial adalah:

1. Trust (kepercayaan),

Trust (kepercayaan) dapat mendorong seseorang untuk bekerjasama dengan orang lain untuk memunculkan aktivitas ataupun tindakan bersama yang produktif. Trust merupakan produk dari norma-norma sosial kooperation yang sangat penting yang kemudian menunculkan modal sosial.

2. Reciprocal (timbal balik),

Unsur penting kedua dari modal sosial adalah reciprocal (timbal balik), dapat dijumpai dalam bentuk memberi, saling menerima dan saling membantu yang dapat muncul dari interaksi sosial (Soetomo, 2006: 87).

3. Interaksi sosial.

Dalam fiqih muamalah begitu juga dalam ekonomi, social capital atau modal sosial juga berperan penting karena dalam menjalankan sebuah instutsi hal ini merupakan modal yang bepengaruh terhadap keberhasilan sebuah usaha atau kegiatan organisasi, tanpa adanya

12 Juhaya S. Praja, Ekonomi Syariah (Bandung: Pustaka Setia, 2012), hal. 56.

${ }^{13}$ Haris El Mahdi, "Menemukan Kembali Kapital Sosial Bangsa Indonesia" Jurnal Ekonomi Volume 12 No 36 Edisi Oktober 2012 halaman 25 
modal sosial memungkinkan kerjasama diantara suatu kelompok atau masyarakat sosial di dalam sebuah lembaga/perusahaan akan menjadi kendala tersendiri. Keberhasilan individu, perusahaan, organisasi dimungkinkan karena prinsip dasar modal sosial yang menekankan pentingnya menjaga hubungan baik dan kepercayaan baik antara sesama warga masyarakat. ${ }^{14}$ Karena Salah satu kekuatan dan energy modal sosial adalah kemampuan menjembatani atau menyambung relasi-relasi antar individu dan kelompok yang berbeda identitas asal. ${ }^{15}$ Modal social menjadi penting, karena banyak aspek yang harus dipertimbangkan dalam rangka untuk mencapai tujuan perusahaan atau organisasi.

Dalam ajaran islam, Ibadah ghoiru mahdloh dan Ibadah mahdloh sama-sama memiliki nilai (manfaat) secara ekonomi maupun non ekonomi. Namun, dalam hal ini salah satu bentuk perekonomian yang disinggung dalam al Qur'an, sunnah dan konsensus para ulama (Ijma) adalah bai' (jual beli). Para pakar yang memiliki konsentrasi dalam bidang ekonomi banyak mencurahkan tenaga dan pemikirannya untuk menggali potensi ekonomi bisnis dalam bentuk ibadah muamalah (ghoiru mahdloh) salah satunya yang kami nuqil adalah pendapatnya ibnu qadamah.

$$
\text { قال ابن قدامة: البيع جائز بالكتاب و السنة و الإجماع16 }
$$

Adapun dari alquran dan hadist:

1) QS. Al-Baqarah 198

2) HR. Bukhori

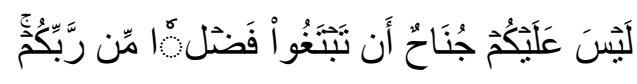
وروى البخاري عن ابن و عبّاس, كانت عكاظ, ومجنّة, وذو المجاز, اسو اقاً في الجاهلية,

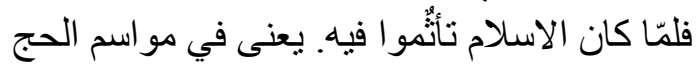

Makna dari hadits yang diriwayatkan imam Bukhori di atas menunjukkan bahwa apa yang tersebut dalam fiqih ibadah (mahdloh) yaitu haji juga terdapat amaliah yang juga identik dengan pelaksanaan

${ }^{14}$ Rusdi Syahra, "Modal Sosial: Konsep dan Aplikasi” dalam Jurnal Masyarakat dan Budaya, Volume 5 No. 1 Tahun 2003 hal 10

15 Suparman Abdullah POTENSI DAN KEKUATAN MODAL SOSIAL DALAM SUATU KOMUNITAS dalam Jurnal Socius VOLUMEI 12 - Januari 2013 halaman 12

${ }^{16}$ Ali Ahmad al- Salusi, Kitab "Fiqhul Ba $i$ wal istitsaq” (Mesir: Maktabah Darul Quran, 2004) Hlm.19-20 
fiqih muamalah (ghoiru mahdloh). Di dalam pelaksanaan jual beli juga ada tata cara (syarat dan rukun) yang harus dijalankan. Hal ini berdasarkan pada sebuah hadits.

$$
\text { نهي النبي صلى الله عليه وسلام عن بيع الغرر } 17
$$

Pentafsirsan hadits di atas adalah terkait larangan jual beli yang mengandung unsur penipuan (ghurur), salah satu contohnya adalah menjual burung yang kondisinya masih terbang di udara tidak juga meskipun burung tadi jinak atau liar dikarenakan tidak terjadinya serah terima pada saat itu. Seperti larangan akan jual beli yang mengandung unsur penipuan, agama juga melarang jual beli yang mengandung unsur riba berdasarkan hadits nabi, sebagai berikut:

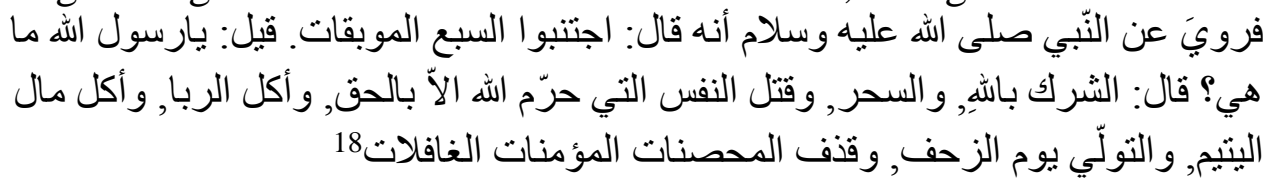

Contoh kajian fiqih muamalah (ekonomi) antara lain adalah jual beli. Jual beli dalam istilah fiqih disebut dengan al-bai' yang berarti menjual, mengganti, dan menukar sesuatu dengan sesuatu yang lain. Lafal albai' dalam bahasa Arab terkadang digunakan untuk pengertian lawannya, yakni kata asy-syira (beli). Dengan demikian, kata al-bai' berarti jual, tetapi sekaligus juga berarti beli. ${ }^{19}$

Dasar hukum jual beli dalam Al-Qur'an disebutkan dalam surat al-Baqarah ayat 275 yang artinya Orang-orang yang makan (mengambil) riba tidak dapat berdiri melainkan seperti berdirinya orang yang kemasukan syaitan lantaran (tekanan) penyakit gila keadaan mereka yang demikian itu, adalah disebabkan mereka Berkata (berpendapat), Sesungguhnya jual beli itu sama dengan riba, padahal Allah Telah menghalalkan jual beli dan mengharamkan riba. Orang-orang yang telah sampai kepadanya larangan Tuhannya, lalu terus berhenti (dari mengambil riba), maka baginya apa yang telah diambilnya dahulu (sebelum datang larangan); dan urusannya (terserah) kepada Allah. Orang yang kembali (mengambil riba), maka orang itu adalah penghuni-penghuni neraka; mereka kekal di dalamnya.

17 “Fiqhul Ba i wal istitsaq” (Mesir: Maktabah Darul Quran, 2004) Hlm. 179

18 "Fiqhul Ba i wal istitsaq" (Mesir: Maktabah Darul Quran, 2004) Hlm. 233

${ }^{19}$ Haroen, Nasrun, Fiqh Muamalah, Jakarta: Gaya Media Pratama, 2000, Hlm. 111 
Berdasarkan ayat tersebut dapat diambil pemahaman bahwa Allah telah menghalalkan jual beli kepada hamba-hamban-Nya dengan baik dan melarang praktek jual beli yang mengandung riba. Dalam persfektif penyususun dikatakan riba jika jual beli mengandung kemafsadatan, dengan bertambahnya kemiskinan baik secara individu maupun kelompok masyarakat.

\section{Fiqih Ibadah dan Fiqih Muamalah}

Realitas dalil aqli dan dalil naqli menunjukan bahwa pada hakikatnya tidak ada pemisahan yang jelas antara fiqih ibadah dan fiqih muamalah. Dalam artian fiqih ibadah berdampak pada urusan akhirat dan fiqih muamalah berdampak pada kehidupan dunia. Karena sesungguhnya setiap perbuatan manusia akan memiliki implikasi baik di dunia maupun di akhirat.

Dalam hal thaharoh maupun sholat sarana untuk mencapai kesempurnaan memerlukan keterlibatan alat ataupun teknologi. Ini menunjukan bahwa sisi fiqih muamalah kehadirannya diperlukan dalam kesempurnaan dan kemudahan pelaksanaan fiqih muamalah. Fakta yang perlu diperhatikan juga dalam pelaksanaan ibadah haji dan umroh. Keduanya hal ini merupakan fiqih ibadah namun menjadi sumber pendapatan bagi negara Arab Saudi. Tercatat tidak kurang dari 2 juta warga dunia datang ke Makkah untuk menunaikan ibadah tersebut, dan mampu menjadi pemasukan negara kedua terbesar bagi Saudi.

Hampir dua juta jemaah dari berbagai negara berkumpul di Kota Suci Makkah selama musim haji. Menurut para pakar, ibadah haji dan umrah punya pengaruh pertumbuhan ekonomi yang signifikan dan membuka lapangan kerja cukup luas bagi warga Saudi. Para ahli ekonomi Arab Saudi Mengatakan bahwa perkiraan pendapatan haji dan umroh akan mencapai lebih dari 150 Miliar dolar AS pada tahun 2022. ${ }^{20}$ Menurut mantan anggota komite nasional kamar dagang dan industri arab Saudi, Makkah Saad bin Jameel al-quraishi sekitar lima juta orang akan berangkat umrah setiap tahunnya sehingga kemungkinan pendapatan dari ibadah umrah sekitar Rp702 triliun pada tahun 2020. ${ }^{21}$ Begitu juga bagi

20 https://www.republika.co.id/berita/jurnal-haji/berita-jurnal-haji/18/06/23/pas1g1385-devisahaji-tahun-2022-saudi-mencapai-220-miliar-dolar-as

21 https://www.cnnindonesia.com/internasional/20160428195356-120-127388/pendapatan-saudidari-umroh-capai-rp702-t-pada-2020 
Negara Indonesia dana abadi haji turut menyumbangkan dalam berbagai kegiatan pendididkan juga menampung tenaga yang cukup signifikan untuk pelaksanaan haji dan umroh, Berdasarkan laporan badan pengelolaan Keuangan Haji (BPKH) dana haji sepanjang tahun 2018 adalah sebesar 113 triliun. ${ }^{22}$

Hasil kajian para ilmuwan disamping pengaruh ekonomi juga banyak pengamat yang berkesimpulan, pemicu perilaku radikal dan terorisme adalah faktor psikologis: ketidakmampuan mengontrol diri, ingin cepat meraih harapan tanpa proses alami; putus asa akibat tereliminasi dari lingkungannya; kecewa dengan kebijakan pemerintah atau kecewa dengan kondisi lingkungan sosial di mana mereka tinggal. Para ilmuwan terjebak pada realitas yang ada tanpa melihat konstruksi berfikir awal yang melakukan pemilahan fiqih ibadah dan fiqih muamalah.

\section{Tafsir at- Tabari}

Realitas yang terjadi justru memprihatinkan generasi muda Islam bahkan rela mengorbankan dirinya untuk mencari kebahagiaan akhirat dengan bom bunuh diri dengan menggunakan logika jihadnya. Hal ini berbanding terbalik dengan tujuan diturunkannya syariat agama (maqasidu syar 'iyah) QS. Al Maidah ayat 62. ${ }^{23}$

Pemahaman ayat "wama kholaqtul jinna wall insa illa liya `budun" (QS. adzariyat 56) harus difahami sebagai bentuk pemberitahuan bahwa setiap aktifitas akan dinilai sebagai ibadah, jika baik akan diberi imbalan berupa pahala dan akan berimplikasi pada surga sebaliknya jika buruk akan diberi balasan dosa dan akan berimplikasi pada neraka ${ }^{24}$, di dalam alqur`an surah yang lain secara lebih mendetail Allah SWT menjelaskan bahwa seluruh perbuatan yang dilakukan manusia di dunia akan diperhitungkan dan diberi pembalasan. Pada hari kebangkitan kelak manusia dikumpulkan menjadi dua kelompok, untuk menerima pembalasan (yaumul hisab) berdasarkan amal perbuatannya ketika menjalani kehidupan dan menunaikan amanah (khalifatullah fil ardh) di dunia (QS. $99: 6-8) .{ }^{25}$

\section{Tafsir Ibn Katsir}

${ }^{22}$ data dari KeuMenkeu.co.id. Media Keuangan Edisi Juli 2019

${ }^{23}$ Izzudin Abdilaziz bin Abdissalam al-sulami, Kitab "Nubadzu min Maqasidi al-Kitab al-Aziz" (Damaskus: Maktabah al- Ghazali, cetakan pertama 1995) Bab. Madhmun alkitab, hlm. 25

${ }^{24}$ Isham Faris al- Hurasan, Kitab "Tafsir Thabari; Jaami al-bayan an ta wil aayil qur 'an” (Bairut: Muasasah al-Risalah, 1994) Jilid 7, Hlm. 124

25 “Tafsir Thabari; Jaami al-bayan an ta 'wil aayil qur 'an” (Bairut: Muasasah al-Risalah, 1994) Jilid 7, Hlm. 555 
Pemahaman ayat "wama kholaqtul jinna wall insa illa liya 'budun” (QS. adzariyat 56) bahwa Allah menciptakan mahluk tiada lain untuk melakukan penghambaan dan mengesakan-Nya. Dia akan memberi balasan yang lebih sempurna dari amaliah yang telah dilakukan hamba yang taat kepada-Nya dan memberi hukuman bagi yang melanggar ketentuan-Nya dengan balasan pedih lagi menyakitkan. Demikianlah ketententuan yang telah dibuat sejak masa azali. $^{26}$ Maknanya ketentuan yang Allah buat di atas bukan karena Allah butuh terhadap mahluk namun, justru demi kebutuhan, Kebaikan (Mashlahah), bagi mahluk itu sendiri. Ditegaskan dengan QS. 99: 78 bahwa tidak ada yang terlepas dari pengawasan Allah seluruh perbuatan manusia (bani adam) yang tampak (visible) maupun (invisible) yang tersembunyi. ${ }^{27}$

Munculnya penggunaan istilah fiqih muamalah dan fiqih ibadah bisa jadi menyumbangkan banyak implikasi dimasyarakat, antara lain adalah keengganan untuk melakukan aktifitas yang tidak dikategorikan sebagai fiqih ibadah. padahal sesungguhnya fiqih ibadah pasti melalui fiqih muamalah dan fiqih muamalah bersinggungan dengan fiqih ibadah. ${ }^{28}$

\section{E. Emosi Keagamaan}

Emosi keagamaan akan masuk kepada masyarakat atau golongan yang memiliki kerentanan tertentu. Rentan dalam makna memiliki akses komunikasi, media, jamaah, ajaran dll. Sehingga ketika ajaranya hanya untuk mengajak kebahagiaan akhirat, dengan sendirinya perbuatan yang dikelompokan kedalam perbuatan duniawi ditinggalkan, tanpa melihat dalil lain yang memiliki makna menafikan aspek dunia maupun akherat semata, sebagai contoh adanya unsur niat. Niat menjadi unsur utama dalam setiap amalan. Peran niat dalam kontek pelaksanaan fiqih muamalah menjadi sangat penting agar perbuatan dikelompokan ke dalam perbuatan dunia yang berimplikasi pada kebahagiaan akhirat. Begitu juga dalam fiqih

\footnotetext{
${ }^{26}$ Sami bin Muhamad as-Salamah, "Tafsir Alquran al-Adhim li Ismail bin Umar bin Katsir alquroys" (Kingdom of Saudi Arabiah: Darul Thoyibah, cetakan ke 2 1999) Juz. 7, Hlm. 425

${ }^{27}$ Muhamad bin Ahmad bin Abu Bakar al-Qurtubi "Jami” al-Ahkam al-Quran wal mubayinu lima tadhamanahu min al-sunnah wa ayyi al-quran " (Bairut: Muasasah al-Risalah, 2006) Juz 22, Hlm. 421
} 
ibadah peran niat menjadi central diterimanya sebuah perbuatan baik disisi Allah.

Dalam hadits yang diriwayatkan oleh Imam Nawawi rahimahullahu ta'ala, dari Amirul Mukminin, Abu Hafsh 'Umar bin AlKhattab radhiyallahu 'anhu, beliau berkata bahwa ia mendengar Rasulullah shallallahu 'alaihi wa sallam bersabda,

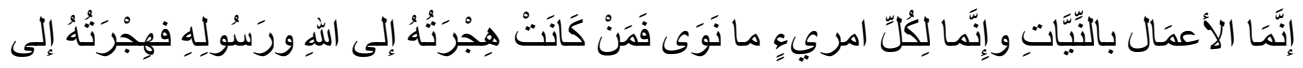

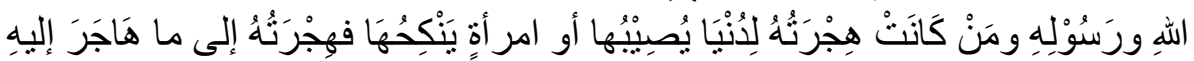
"Sesungguhnya setiap amalan tergantung pada niatnya. Dan sesungguhnya seseorang hanya mendapatkan apa yang dia niatkan. Maka barang siapa yang hijrahnya karena Allah dan Rasul-Nya, maka hijrahnya untuk Allah dan Rasul-Nya. Siapa yang hijrahnya karena mencari dunia atau karena wanita yang dinikahinya, maka hijrahnya kepada yang ia tuju." (HR. Bukhari dan Muslim)

Lebih tegas lagi disampaikan dalam hadits lain bahwa niat atau azam (berkeinginan kuat) lebih memiliki nilai dibandingkan dengan amalanya. Sebagaimana hadits Rasululullah SAW yang diriwayatkan oleh Al-Baihaqi yang berbunyi:

نِيْةُ المُؤْمِنِ خَيْرُ مِنْ عَمَلِهِ Artinya: "Niat seorang mukmin lebih utama dari pada amalnya."

Berdasarkan dalil diatas sangat jelas dalam hal perbuatan manusia bukan tergantung kepada pengelompokan fiqih ibadah atau pada fiqih muamalah untuk menjadi berpahala atau dapat imbalan surga, akan tetapi perbuatan manusia dapat bergantung kepada niat untuk menjadi berpahala, karena dengan niat, seseorang bisa mendapat implikasi kebahagiaan akherat dalam bentuk surga.

Pemahaman umat tentang fiqih ibadah untuk amalan akhirat dan fiqih muamalah untuk urusan dunia saja menjadi rancu ketika melihat pemahaman ayat "wama kholaqtul jinna wall insa illa liya 'budun” (qs. adzariyat 56). Dalil ini harus difahami sebagai bentuk pemberitahuan bahwa setiap aktifitas akan dinilai sebagai ibadah, jika baik akan diberi

28 Ahmad bin Muhamad al- Zarqa, "Syarah Qawa`idul Fiqhiyah” (Damaskus: Darul Qalam, 1987) Hlm. 47 
imbalan berupa pahala dan akan berimplikasi pada surga (jannah), jika buruk akan diberi balasan dosa dan akan berimplikasi pada neraka (nar). Jadi sesungguhnya pemisahan perbuatan didunia semata dan akhirat semata kurang tepat dalam agama tetapi semua perbuatan itu selalu berdampak di dunia dan akhirat.

Kontruksi berfikir memilah mana perbuatan dunia dan mana perbuatan akhirat akan menjadikan perilaku umat menjadi terkotak-kotak dan akhirnya akan memunculkan perilaku yang lebih mengarah hanya pada perbuatan akhirat dan berdampak pada perilaku radikal. karena hanya beranggapan satu perbuatan pasti akan berdampak pada kebaikan akhirat. Unsur niat dan dampak dari perbuatan di dunia dianggap tidak penting, ketika perbuatan itu dikategorikan sebagai fiqih muamalah, karena diksi pemilahan perbuatan dunia dan perbuatan akhirat semata.

Ketaatan terhadap agama dengan menafikan perbuatan lainya sebagai ajaran yang diperhitungkan oleh allah akan berevolusi menjadi "perilaku radikal" yang akhirnya akan menyebabkan suburnya emosi keagamaan, padahal seharusnya ketaatan terhadap agama justrtu akan memunculkan cinta Allah dan cinta sesama yang merupakan hakikat dari agama Islam.

\section{F. Kesimpulan}

1. Setiap permbuatan manusia selalu berimplikasi pada akhirat, tidak ada perbuatan manusia yang hanya di dunia dan hanya di akhirat semata. Setiap perbuatan manusia pastinya akan dicatat sebagai amalan dan berakibat pada dosa atau pahala dan implikasinya pada surga ataupun neraka. Jadi baik fiqih ibadah maupun muamalah memiliki implikasi di dunia maupun akhirat,

2. Pemahaman fiqih ibadah dan muammalah (Ekonomi) yang dibuat hitam putih dalam pemahamanya dapat berdampak terhadap perilaku radikal, dan implikasinya dapat menghilangkan kecintaan kepada Allah dan sesama umat.

\section{Daftar Pustaka}


Abdurahman as-Suyuthi. 1983. Asybah wa Nadhair. Bairut: Darul Kitab Alamiyah.

Abdurrahman bin Nasir Al Barrak, Abu Qutaibah N. M. Al Faryabi. 2005. Fathul Barri bi Syarhil Bukhori. Riyadh : Darul Thaibah. Abi Yahya Zakaria al- Anshori. 2008. Fathul Wahab bi Syarhi Minhaju at-Thulab. Al Haramain.

Adiwarman Karim, 2010. Bank Islam: Analisis Fiqh \& keuangan, Jakarta: PT.Raja Grafindo Persada, Edisi 4,cet 7.

Ahmad bin Muhamad al- Zarqa. 1987. Syarah Qawa idul Fiqhiyah. Damaskus: Darul Qalam.

Ali Ahmad al- Salusi. 2004. Kitab "Fiqhul Ba i wal istitsaq”. Mesir: Maktabah Darul Quran.

Faris al Hurasan, Isham. 1994. Kitab "Tafsir Thabari; Jaami al-bayan an ta 'wil aayil qur 'an”. Bairut: Muasasah al-Risalah

Haroen, Nasrun. 2000. Fiqh Muamalah, Jakarta: Gaya Media Pratama.

Izzudin Abdilaziz bin Abdissalam al-sulami. 1995. Kitab "Nubadzu min Maqasidi al-Kitab al- Aziz”. Cet-1. Damaskus: Maktabah alGhazali

Kasmir, bank \& Lembaga Keuangan Lainnya, Jakarta: PT.Raja Grafindo Tinggi, Ct ke 6 .

Muhamad bin Ahmad bin Abu Bakar al-Qurtubi. 2006. Jami al-Ahkam al-Quran wal mubayinu lima tadhamanahu min al-sunnah wa ayyi al-quran. Bairut: Muasasah al-Risalah

Nawawi, Muhammad. Syarhul Muraqil 'Ubudiyah. Pekalongan: Maktabah Raja Murah.

Rasyid, Muhamad. 1999. Kitab "Ashbabunnuzul wa atsariha fibayani nushus". Darus Syihab.

Sami bin Muhamad as-Salamah. 1999. Tafsir Alquran al-Adhim li Ismail bin Umar bin Katsir al-quroys. Cet-2. Kingdom of Saudi Arabiah: Darul Thoyibah.

Z, Wahbah. 2005. Kitab “Fiqhul islami wa adalatih". Damaskus: Maktabah Darul Fikr

. 2004. Fiqhul Ba`i wal istitsaq. Mesir: Maktabah Darul Quran. . 1994. Tafsir Thabari; Jaami al-bayan an ta`wil aayil qur`an. Bairut: Muasasah al-Risalah.

—. Kitab "Majmu li Nawawi

—. 2005. Fiqhul islami wa adalatih. Damaskus: Maktabah Darul Fikr 
Fiqih Ibadah Versus Fiqih Muamalah (237-254) 